\title{
Phytoprotection
}

\section{A note on the chronic effects of tall oil on the variegetd cutworm, Peridroma saucia [Lepidoptera : Noctuidae]}

\section{Y.S. Xie et M.B. Isman}

Volume 73, numéro 3, 1992

URI : https://id.erudit.org/iderudit/706028ar

DOI : https://doi.org/10.7202/706028ar

Aller au sommaire du numéro

\section{Éditeur(s)}

Société de protection des plantes du Québec (SPPQ)1

\section{ISSN}

0031-9511 (imprimé)

1710-1603 (numérique)

Découvrir la revue

\section{Citer cet article}

Xie, Y. \& Isman, M. (1992). A note on the chronic effects of tall oil on the variegetd cutworm, Peridroma saucia [Lepidoptera : Noctuidae]. Phytoprotection, 73(3), 119-121. https://doi.org/10.7202/706028ar

\section{Résumé de l'article}

Les effets chroniques de la résine liquide (tall oil), un sous-produit de l'industrie papetière, sur le ver-gris panaché, Peridroma saucia, ont été évalués par son incorporation à une diète artificielle. À une concentration de 1,5\% en poids frais de la diète, la résine liquide dépoissée a réduit significativement le poids du P. saucia, a prolongé son temps de développement et a augmenté la mortalité des divers stades. Une relation linéaire significative a été trouvée entre la concentration de résine dans la diète ettoutes les données de développement évaluées. Une expérience de changement de diète a clairement démontré que l'effet inhibiteur de la résine envers le P. saucia est persistant et n'est pas automatiquement supprimé par le transfert de larves à une diète non traitée. La résine peut être un agent de lutte naturel efficace dans la lutte au ver-gris panaché. 


\title{
A note on the chronic effects of tall oil on the variegated cutworm, Peridroma saucia [Lepidoptera: Noctuidae]
}

\author{
Yongshou S. Xie ${ }^{1}$ and Murray B. Isman ${ }^{1,2}$
}

Received 1992-06-10; accepted 1992-12-09

Chronic effects of tall oil, a by-product of the kraft pulping process of softwoods, on the variegated cutworm, Peridroma saucia, were assessed via incorporation into artificial diet. At a dietary concentration of 1.5\% fresh weight, depitched tall oil (DTO) significantly reduced $P$. saucia weight, prolonged developmental time, and increased mortality in different stages. A significant linear relationship was found between dietary concentration of DTO and all developmental parameters tested. A diet-shift experiment clearly demonstrated that the inhibitory effect of DTO to $P$. saucia is persistent and not readily alleviated by transferring larvae to untreated diet. DTO may be a useful natural agent for pest management.

\section{Xie, Y.S., and M.B. Isman. 1992. A note on the chronic effects of tall oil on the variegated cutworm, Peridroma saucia [Lepidoptera: Noctuidae]. PHYTOPRO- TECTION 73: 119-121.}

Les effets chroniques de la résine liquide (tall oil), un sous-produit de l'industrie papetière, sur le ver-gris panaché, Peridroma saucia, ont été évalués par son incorporation à une diète artificielle. À une concentration de 1,5\% en poids frais de la diète, la résine liquide dépoissée a réduit significativement le poids du $P$. saucia, a prolongé son temps de développement et a augmenté la mortalité des divers stades. Une relation linéaire significative a été trouvée entre la concentration de résine dans la diète et toutes les données de développement évaluées. Une expérience de changement de diète a clairement démontré que l'effet inhibiteur de la résine envers le $P$. saucia est persistant et n'est pas automatiquement supprimé par le transfert de larves à une diète non traitée. La résine peut être un agent de lutte naturel efficace dans la lutte au ver-gris panaché.

Higher plants are a rich source of secondary metabolites, some of which possess insecticidal and/or antifeedant bioactivities (Arnason et al. 1989). As host-plant selection by phytophagous insects is largely based on the presence of specific attractants or the absence of feeding deterrents (Schoonhoven 1982), there is potential for the use of insect antifeedants in pest management programs. However, the actual use of antifeedants of natural

1. Department of Plant Science, University of British Columbia, Vancouver, British Columbia, Canada V6T $1 Z 4$

2. Author to whom all correspondence should be addressed. origin as dependable insect control agents has yet to be realized (Schoonhoven 1982). One reason for this is the non-persistence or minimal residual activity of insect antifeedants (Griffiths et al. 1991).

Tall oil, a by-product of the kraft pulping process of softwoods, has demonstrated antifeedant effects and toxicity against phytophagous insects (Cousin 1989; Xie and Isman 1992). Diterpene resin acids are likely the major bioactive principles in tall oil against the variegated cutworm, Peridroma saucia Hübner [Lepidoptera: Noctuidae]. The present report examines chronic effects of depitched tall oil on larval and pupal development of $P$. sau- 
cia, and demonstrates that the growth inhibitory effect on $P$. saucia persists after exposure to tall oil is discontinued.

Depitched tall oil (DTO) (BC Chemicals Ltd., Prince George, British Columbia, Canada) was incorporated into an artificial diet (BioServ Inc., Frenchtown, New Jersey) at concentrations of 1.0, 1.5, 2.0, and $2.5 \%$ fresh weight. Control diet was treated with carrier methanol alone. Fifty neonate larvae were individually placed in cells of a plastic tray with treated or control diet. Larvae were maintained in a growth chamber at $25^{\circ} \mathrm{C}$, and a photoperiod of $16 \mathrm{~h}$ light and $8 \mathrm{~h}$ dark. Appropriate diets were provided ad libitum. The following developmental parameters of $P$. saucia were examined: mean maximum weight of last instar, larvae mortality prior to pupation, days to pupation, pupal weight, pupal mortality, days to adult emergence, mean adult weight.

A diet-shift experiment was performed to determine if older larvae are sensitive to dietary DTO and also if larvae spontaneously recover from the growth inhibitory activity of DTO after exposure is discontinued. Twenty third-instar larvae (average weight $=5 \mathrm{mg}$ ) were individually reared on either control diet or diet containing $2.0 \%$ DTO for $4 \mathrm{~d}$, after which half of each cohort was transferred to the opposite diet (i.e. control to treated diet, treated to control diet). Larvae were then allowed to feed on the new diet for $4 \mathrm{~d}$. All larvae were weighed daily.

All data were analyzed using linear regression analyses by a statistical program (Anonymous 1991). Analyses of covariance (ANCOVA) was used to compare slopes in the diet-shift experiment (Zar 1984).

When DTO was incorporated into artificial diet at concentrations of $\geq 1.0 \%$ fresh weight, it significantly $(P \leq 0.05)$ reduced maximum weight of last instar larvae, prolonged larval and pupal development, and increased larval and pupal mortality compared with controls (Table 1). Pupal and adult weights were also reduced by DTO, but these are likely consequences of reduced maximum weight of larvae prior to pupation. A significant $(P \leq 0.05)$ linear relationship was found between dietary concentration of DTO and all developmental parameters tested (Table 1).

The results from the diet-shift experiment clearly demonstrated that the inhibitory effect of DTO to $P$. saucia is persistent and not readily alleviated by transferring larvae to untreated diet. After $4 \mathrm{~d}$, mean weight of larvae transferred to con-

Table 1. Effects of depitched tall oil on developmental parameters of Peridroma saucia ${ }^{a}$

\begin{tabular}{|c|c|c|c|c|c|c|c|}
\hline \multirow[b]{2}{*}{$\begin{array}{c}\text { Dietary } \\
\text { concentration } \\
\text { (\% fresh wt.) }\end{array}$} & \multicolumn{3}{|c|}{ Larvae } & \multicolumn{2}{|c|}{ Pupae } & \multicolumn{2}{|c|}{ Adult } \\
\hline & $\begin{array}{l}\text { Maximum wt. } \\
\text { of last instar } \\
\text { (mg) }\end{array}$ & $\begin{array}{c}\text { Mortality } \\
(\%)\end{array}$ & $\begin{array}{l}\text { Number of } \\
\text { days to } \\
\text { pupation }\end{array}$ & $\begin{array}{l}\text { Mean wt. } \\
\text { (mg) }\end{array}$ & $\begin{array}{c}\text { Mortality } \\
(\%)\end{array}$ & $\begin{array}{l}\text { Number of } \\
\text { days to } \\
\text { emergence }\end{array}$ & $\begin{array}{l}\text { Mean wt. } \\
\text { (mig) }\end{array}$ \\
\hline 0 & $1036.0(139.4)$ & 0 & $23.8(0.8)$ & $421.6(44.0)$ & 22.4 & $14.4(1.7)$ & $250.3(38.3)$ \\
\hline 1.0 & $728.6(133.8)$ & 8.0 & $28.7(1.8)$ & $385.8(41.9)$ & 39.0 & $15.8(1.3)$ & $232.9(41.9)$ \\
\hline 1.5 & $668.7(126.8)$ & 22.0 & $33.1(1.8)$ & $332.4(61.5)$ & 42.4 & $16.4(1.3)$ & $202.5(24.1)$ \\
\hline 2.0 & $717.0(168.9)$ & 32.0 & $34.0(2.1)$ & $354.7(51.5)$ & 40.0 & $17.2(1.7\rangle$ & $185.3(26.8)$ \\
\hline 2.5 & $650.8(162.4)$ & 36.0 & $35.0(1.7)$ & $323.8(64.6)$ & 45.8 & $17.4(1.5)$ & $173.6(27.5)$ \\
\hline
\end{tabular}

Regression parameters ${ }^{\mathrm{b}}$ :

\begin{tabular}{lccccccc} 
Interception & 1000.1 & -3.8 & 23.5 & 424.0 & 23.9 & 14.3 & 258.0 \\
Slope & -697.3 & 68.0 & 21.5 & -175.5 & 40.9 & 5.6 & -142.8 \\
$R$-value & 0.94 & 0.94 & 0.98 & 0.93 & 0.96 & 0.99 & 0.94 \\
$P$-value & 0.0170 & 0.0175 & 0.0026 & 0.0238 & 0.0101 & 0.0012 \\
\hline
\end{tabular}

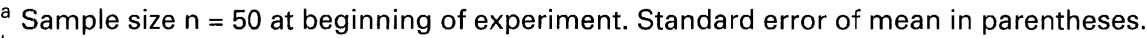

${ }^{b}$ Linear regression performed within columns after a logarithmic transformation $[\log (X+1)$, where $\mathrm{X}=$ DTO dietary concentration]. 
trol diet from DTO treated diet did not differ significantly from that of larvae remaining on the DTO treated diet (Figure 1A). The covariance analysis also supported this conclusion. Slopes of growth curves for larvae on treated diet exclusively and for larvae transferred from treated to control diet were 21.1 and 23.9, respectively, and not significantly different (Figure 1B), indicating that alleviation of toxicity is slow. This experiment also indicated that DTO significantly $(P \leq 0.05)$ inhibited growth of fourth-instar larvae. Slopes of growth curves for larvae on control diet exclusively and for larvae transferred from control to treated diet were 75.8 and 51.4, respectively, and significantly different $(P \leq 0.05)$ (Figure 1B).

Habituation of insects to antifeedants is a basic concern for their potential use (Schoonhoven 1982). In some cases, insects can adapt to antifeedant compounds
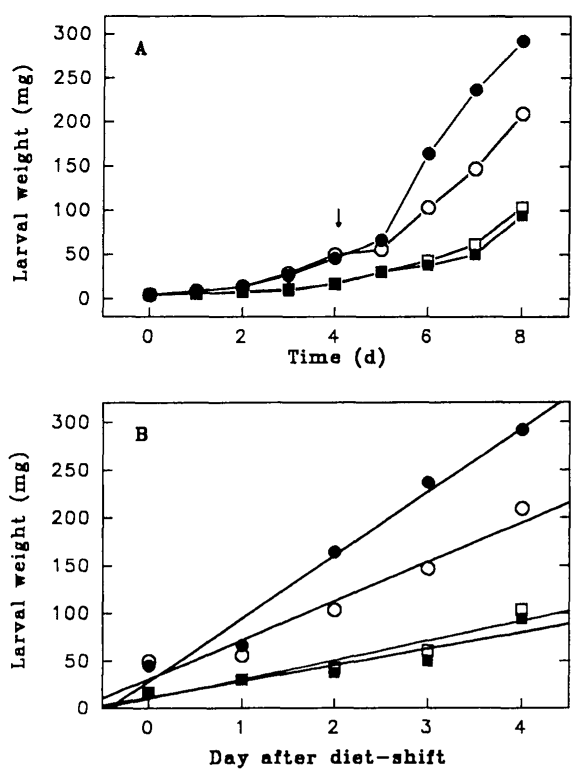

Figure 1. A) Larval growth of $P$. saucia on control and DTO-treated ( $2.0 \%$ fresh weight) artificial diet and transferred to the opposite diets (Vertical arrow indicates the day on which larvae were transferred), and B) linear relationship of different treatments after diet shift. $10=$ on control diet exclusively, $\mathrm{O}=$ transferred from control to treated diet, $\square=$ on treated diet exclusively, $\square=$ transferred from treated to control diet). very rapidly. In the case of DTO, growth inhibition is a consequence of both antifeedant (behavioral) and toxic effects (Xie and Isman 1992), and therefore, habituation is less of a concern. Although DTO has little, if any, contact insecticidal action (acute toxicity), dietary DTO delays both larval and pupal development, increases mortality of both stages, and results in lighter adults with presumably decreased fecundity (Myers 1988). These observations, as well as that of delayed recovery from DTO ( $>4 \mathrm{~d}$ ) after exposure ceases, suggest that DTO may be a useful natural agent for pest management.

\section{ACKNOWLEDGEMENT}

We thank Yanfen Zheng for technical assistance, BC Chemicals Ltd, Prince George, British Columbia, Canada for supplying DTO. This study was supported by grants from NSERC (CRD 112262), Forestry Canada, and BC Chemicals Ltd.

\section{REFERENCES}

Anonymous, 1991. Statistix (3.5) User's Manual. Analytical Software. St. Paul, MN. 308 pp.

Arnason, J.T., B.J.R. Philogène, and P. Morand (eds). 1989. Insecticides of plant origin. ACS Symp. Ser. 387. Washington, DC. 213 pp.

Cousin, M.J. 1989. Tall oil neutrals to protect plants from insects and the like. U. S. Patent. Patent No. 4874610.

Griffiths, D.C., S.P. Maniar, L.A. Merritt, A. Mudd, J.A. Pickett, B.J. Pye, L.E. Smart, and L.J. Wadhams. 1991. Laboratory evaluation of pest management strategies combining antifeedants with insect growth regulator insecticides. Crop Prot. 10: 145151.

Myers, J.H. 1988. The induced defense hypothesis: Does it apply to the population dynamics of insects? Pages 345-365 in K.C. Spencer (ed.), Chemical mediation of coevolution. Academic Press, Inc., London.

Schoonhoven, L.M. 1982. Biological aspects of antifeedants. Entomol. Exp. Appl. 31: 5769.

Xie, Y.S., and M.B. Isman. 1992. Antifeedant and growth inhibitory effects of tall oil and derivatives against the variegated cutworm, Peridroma saucia Hübner (Lepidoptera: Noctuidae). Can. Entomol. 124: 861-869.

Zar, J.H. 1984. Biostatistical analysis. PrenticeHall, Englewood Cliffs, NJ. 718 pp. 